\title{
Analyzing the Values in the Built Heritage of Chettinadu Region, Tamil Nadu, India
}

Seetha RajivKumar ${ }^{1}$ and Thirumaran Kesavaperumal ${ }^{2}$

${ }^{1}$ Department of Architecture, National Institute of Technology, Tiruchirappalli, India

Email: seetha.arch@gmail.com

\section{ARTICLE INFORMATION}

Received: June 18, 2019

Revised: June 27, 2019

Accepted: July 5, 2019

Published online: July 11, 2019

Keywords:

Built Heritage, Architectural Values, Cultural Values, Environmental Values, Chettinadu

\begin{abstract}
Chettinadu, a region in southern India, is situated in Tamil Nadu State $32 \mathrm{~km}$ from the west coast of the Bay of Bengal with a total area of 1,550 square kilometers in the heart of Tamil Nadu. The built heritage of Chettinadu is an irreplaceable cultural resource giving it a unique identity and character. In the tentative list of UNESCO 2014, the Chettinadu region has been classified into three clusters based on their Outstanding Universal Values and this provides a framework for our research.The region has experienced a tremendous amount of change from its original design and the old buildings are mirrors of the procession of history and culture that together have formed the heritage of the town. Well known for its palatial mansions with their unique architectural style, the conservation of old buildings is a must in retaining the character of the city. In this paper we studied the historical background of heritage areas and buildings in the Chettinadu region and attempted to establish the values in the built heritage by means of a selected set of variables. To achieve this objective various parameters were analyzed as how the values of the built heritage contribute to the unique sociocultural flavor of Chettinadu. Social, cultural, historical, and architectural values all enhance the image of the town, but assessing their relative importance for purposes of urban planning is a significant challenge. This analysis support the evolution of strategies targeted at preserving and enhancing the built heritage of the region. The varied heritage potential based on the values will help planners and developers to create sustainable programs for modernizing the infrastructure while protecting the inherent values of the built heritage of Chettinadu.
\end{abstract}

\section{Introduction}

The people of a region inherit a physical environment that is often deeply entangled with the identity of their past as mirrored in the idiosyncratic stock of their built heritage. The definition of heritage was confined to monuments, archaeological sites and collections of movable history until the first half of the 20th century. With the Venice Charter the concept of heritage was extended from monuments and sites to include almost the whole built environment. The ascendancy of a conservation approach to city planning strengthened the idea that values merited more importance and attention in defining the character of a town or region. Identifying the attributes of selected values and varied levels of significance in the built heritage is an important step in historical preservation. Once these are clearly delineated and their significance assessed, then their relative contributions to each aspect of a conservation program can be determined. The term 'heritage values' relates to the meanings assigned to structures, archeological sites, landscapes, traditions, and culture by groups of individuals.
Those values were the principal legitimizing factor in the protection and administration of the heritage, despite the fact that their perception varies from time to time between nations. Understanding what value is meant for a heritage is important because it always has value as a reason for conserving the heritage. Of course no society tries to preserve what it doesn't appreciate. Value categorization helps recognize the value type most frequently connected with particular heritage sites. The analysis starts with the questions:

1. What are the aspects of our built heritage should be considered as 'valuable' and why?

2. How should 'value' be defined?

3. What value does the built heritage add to society?

Conservation has always considered values in making choices and as 'a guiding principle' for decision-making. We need to clearly define the principles on which decisions for conservation efforts are based. The techniques through which we identify the associational dimensions, the 'values', and the attributes need to be defined and discussed. 
Implicit preservation of all actions aimed at maintaining the importance of an item or place of heritage is a method that is initiated once a place has cultural values and has been identified for protection. Conservation is an attempt to regulate and direct the past and current changes. The aim of the research is to find out how the inhabitants view the importance, value and cultural importance of the town in which they reside, which is part of our research of the Chettinadu area, as main stakeholders of this location(R. Seetha \& Dr. K. Thirumaran, 2018). The research will also focus on "threats" and "hazards," which may have adverse consequences for such values, and on how community values can be expressed and linked with expert views to direct fresh opportunities in the maintenance of the built heritage. The rest of this document is organized as follows to try this goal. The first section examines heritage literature. The second section contains information on the field of research. We present equipment, techniques and outcomes in the third portion. In the fourth part, the findings and suggestions are discussed. The last part concludes the paper.

\section{Literature Review}

The historic and heritage values were the values initially ascribed to heritage sites(Hearn, 1990;Ruskin, J., 1885; Ruskin, J., 2013). Riegel, A. (1996) was among the first to classify heritage values into historical and contemporary. The heritage of a region is no longer a static group of fixed objects, but a social process through which "any human artefact is deliberately invested in the memorial." (Choay, F., \&Connell, L. M., 2001). In 1979, the Australian International Council of Monuments and Sites (ICOMOS) issued the Burra Charter, marking an important moment for the development of heritage studies (Australia ICOMOS, 1988). This paper emphasizes the significance of social values, "qualities in which a place for a majority or a minority group focuses on spiritual, political, national and other cultural sentiment" (Australia ICOMOS Guidelines, 1999). The value of human heritage is also learned or discovered, depending on the specific cultural, intellectual, historical and psychological reference frames of the individuals or groups concerned. (Lipe, W. D., 1984).

The historical, aesthetic, economic, social, and scientific values are considered important in all the literature sources. (Riegel, A., 1996; Lipe, W. D., 1984; Mason, R., 2002; Lafrenz Samuels 2008; ICOMOS New Zealand2010) (Table 1). Historical, esthetic and scientific values are the most widely recognized heritage values. Social values in professional assessments are not easily defined because they are contemporary, locally held and not evident in the physical world (Johnston 1992; Walker 1998). However, the protection of towns, regions and landscapes, with the increasing focus on heritage affecting many people's day to day life, has become a significant factor in social values. (MacFarquhar, 2011). We can distinguish two kind of built heritage, tangible and intangible. Regarding tangible heritage, it involves all elements, such as sizes, form, layout, materials, spatial configuration, colours and decorations of buildings, which make a contribution to the spatial configuration of the town. The important identity and image of a city must be reflecting this element. Therefore, it is important to preserve and protect each component.

Table 1. Typology of Values based on Literature sources.

\begin{tabular}{|c|c|}
\hline $\begin{array}{l}\text { Australian } \\
\text { ICOMOS (1979) }\end{array}$ & Aesthetic + Historic + Scientific + Social \\
\hline Lipe (1984) & $\begin{array}{l}\text { Economic }+ \text { Aesthetic }+ \text { Associative } \\
\text { Symbolic }+ \text { Informational }\end{array}$ \\
\hline Alois Reigl (1902) & $\begin{array}{l}\text { Age }+ \text { Historical }+ \text { Commemorative }+ \text { Use } \\
+ \text { Newness }\end{array}$ \\
\hline Choay (1992) & $\begin{array}{l}\text { Aesthetic }+ \text { Cognitive }+ \text { National }+ \\
\text { Economic }\end{array}$ \\
\hline $\begin{array}{l}\text { Cathy lynne } \\
\text { Costin (1993) }\end{array}$ & $\begin{array}{l}\text { Symbolic + Historic + Informational } \\
+ \text { Aesthetic + Economic. }\end{array}$ \\
\hline Bruno Frey (1997) & $\begin{array}{l}\text { Monetary }+ \text { Option }+ \text { Existence }+ \text { Bequest } \\
+ \text { Prestige }+ \text { Educational }\end{array}$ \\
\hline $\begin{array}{l}\text { English Heritage } \\
(1999)\end{array}$ & $\begin{array}{l}\text { Cultural + Educational \& Academic + } \\
\text { Economic + Resource + Recreational }+ \\
\text { Aesthetic }\end{array}$ \\
\hline
\end{tabular}

Burra Charter (1999)

Mason (2002)

Aesthetic + Historic + Scientific + Social (spiritual, political , cultural)

Socio cultural + Aesthetic + Historical + Symbolic + Social + Cultural + Economic

Pereira Roders Aesthetic + Ecologic + Historic + Age + (2007) Social + Scientific + Political + Economic

Artistic + Architectural + Townscape +

Orbasli (2008) Landscape + Historic + Local + Associative + Age $\&$ rarity + Symbolic + Political + Economic

Soheir (2015) Usage + Cultural + Emotional

Ferdous, Rabeya, Historical + Architectural + Group Value Roxana (2017) + Rarity 
As far as the intangible built heritage is concerned, it includes building use, social culture, associations with the history of the city, and sound. Azmi et al. (2015) pointed to the fact that the use of constructions has a crucial role to play in defining a town's financial and social values. On the other hand, the placement of a town's historic link is a main element of the town identity. The Australia ICOMOS (1999) has obviously shown that a site has historic values because of the impact of historical figures, events, phases or activities. A place can also maintain its own symbolic and important significance as some important events and associations happened. Further, Mason, R (2002) stated that age of the site could be taken as a historical value, arguing that heritage does not exist without historical values.

The term ' Heritage values' refers to the meaning of collections, buildings, archaeological sites, landscape, traditions and culture attributed by groups of people. These values (Table 1) were a fundamental factor in legitimizing patrimony protection and management, but their understanding has changed over time and nuances exist between countries.

\section{Background of the Study Area}

\subsection{Profile}

Chettinadu is a region located in the central part of Tamil Nadu state in southern India spread throughout $10^{\circ} 10^{\prime} \mathrm{N}$ latitude and $78^{\circ} 46^{\prime} \mathrm{E}$ longitude (Figure 1) This 1,550 square kilometer area in the heart of Tamil Nadu is home to 110,000 Chettiars who inhabit two major towns and 73 villages. (UNESCO-A concept paper on Chettinad trial in T.N, 2010). Karaikudi in the district of Sivagangai is considered the economic heart of Chettinadu, while Kanadukathan is the major tourist destination. There are two monsoon types, which prevail in the Chettinadu region. The southwest monsoon from July to mid-September which brings an average of $100 \mathrm{~cm}$ rainwater at its peak and the northeast monsoon from October to December which brings heavier rain with an average of $180 \mathrm{ml}$. The Chettiars have devised good water management systems to control the flow of rainwater.

In the scorching and parched region of southeast Tamil $\mathrm{Nadu}$, there existed an allied settlement of about 75 pockets named Chettinadu. The area was distributed across two districts, Sivagangai and Pudukkottai, and was comprised of three clusters with a total of eleven villages. The UNESCO tentative list describes it as forming a unique architectural ensemble of three clusters (Figure 2) with outstanding universal value (OUV):

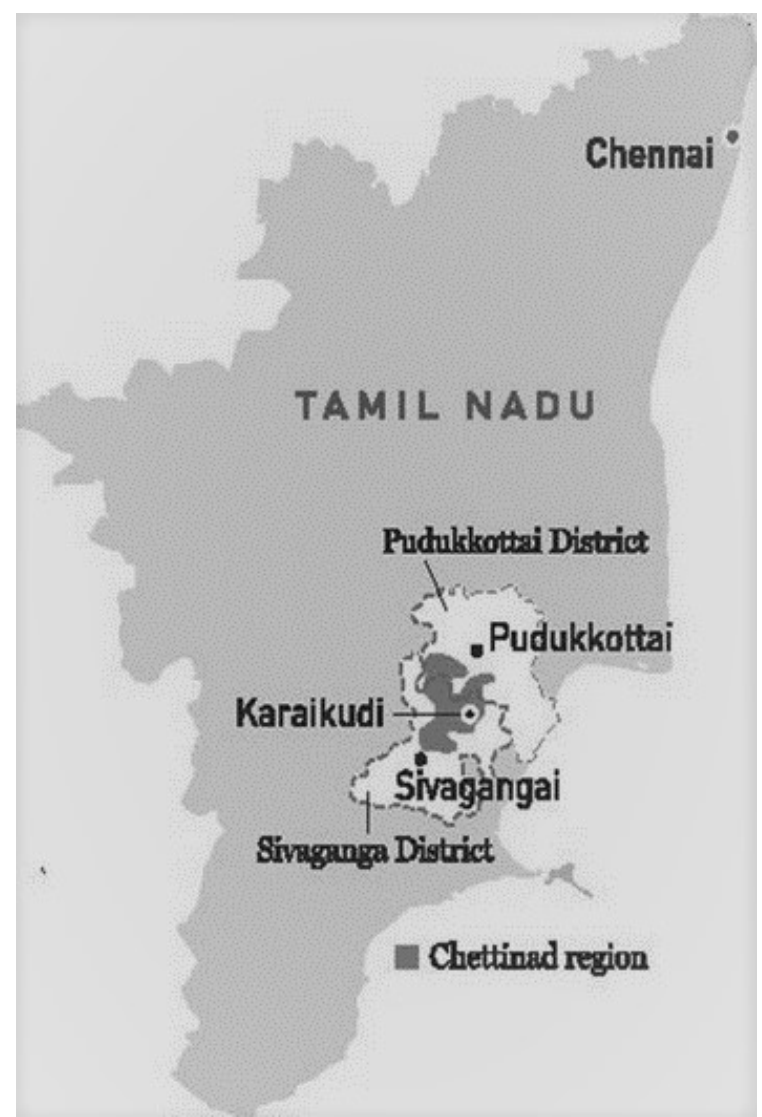

Figure 1. Location map of Chettinad region in Tamil Nadu (Source: https://frontline.thehindu.com/arts-and-culture/heritage/ article25547282.ece)

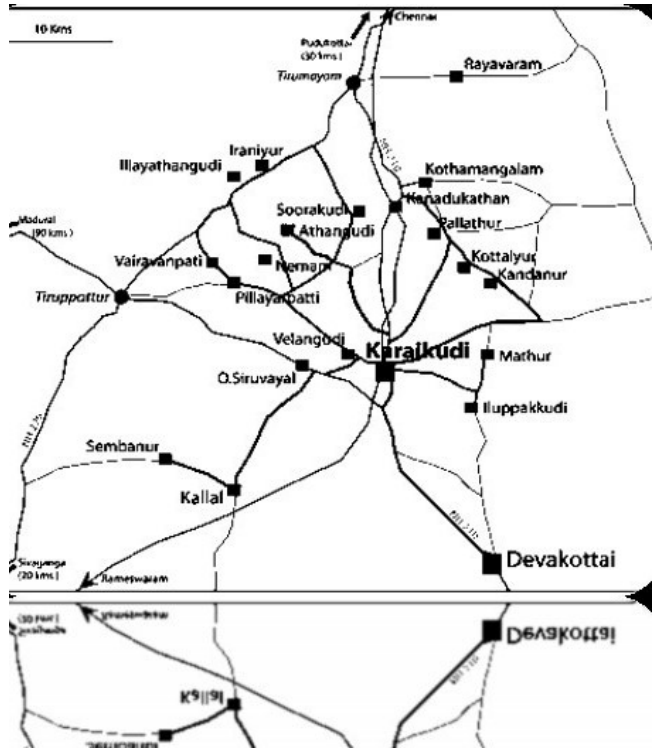

Figure 2. Location map of Chettinad region showing the village clusters (Source: Concept paper, UNESCO, New Delhi) 
- Cluster I (4 settlements):

- Kanadukathan

- Pallathur

- Kothamangalam

- Kottaiyur

- Cluster II (4 settlements):

- Athangudi

- Chokalingampudur

- Karaikkudi

- Kandanur

- Cluster III (3 settlements):

- Rayavaram

- Arimalam

- Kadiapatti- Ramachandrapuram

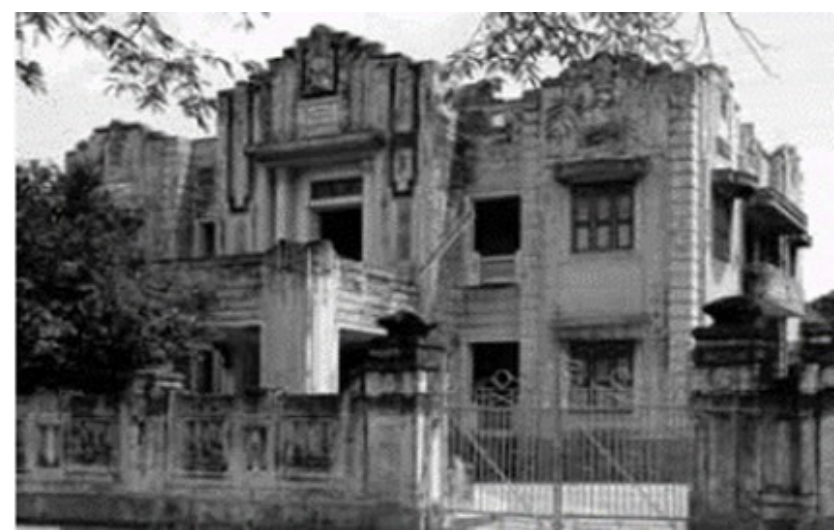

Figure 3. Art Deco house in Kanadukathan (Source: Concept paper, UNESCO, New Delhi)

The Chettinadu region possesses unparalleled cultural assets that symbolize its distinct identity and character all across the globe. This historical center of the town is imbued with the culture, traditions and lifestyles of the inhabitants, and reflects the designs, materials, and architectural styles passed down from generation to generation-a greater legacy than a mere built heritage of stone and mortar (Kiruthiga, K., \& Thirumaran, K., 2017). The region's historical monuments and sacred precincts have suffered over recent decades from lack of proper town planning and the dismissive attitude of the government and common people towards heritage preservation (Goussous, J. S., \& Al-Hammadi, N. A., 2018). Poorly planned urbanization and unregulated tourism threaten built heritages that are neither listed nor protected and are therefore getting erased due to increased demolition. Excessive development in these towns is rapidly and irreversibly transforming their heritage characteristics (Feilden, B. M. \& Jokilehto, J., 1998). Unless this degradation stops, the Indian people shall lose one of its most valued possessions, which is its cultural identity. These priceless buildings and other monuments should be preserved and restored (Vasulingam, V., \& Vedamuthu,
R., 2014) and UNESCO's heritage site listing program has had tremendous success in the last few years in urban conservation. In 2014, UNESCO's tentative listing of Chettinadu's historic structures as a World Heritage Site placed this region of Tamil Nadu on the heritage tourism map. (R.Seetha \& Dr.K.Thirumaran, 2018).

\subsection{Architectural character of Chettinad residences}

These magnificent Chettinadu houses were built between 1840 and 1935.There is an eclectic style in the architecture of the early to mid- $20^{\text {th }}$ century, especially in the Art Deco homes (Figure 3) that were built in the 1940s and 1950s. These buildings are favourite tourist destinations for heritage tours. The centre of a courtyard is exposed to the sun, surrounded by pillars, with a veranda connected to different rooms(Figure 4). People lived in these huge residences as part of an extended family and they required large areas for combined living and also to conduct various activities. Passive architecture strategies were used to achieve indoor thermal comfort. The variety of spaces - open, semi-open and enclosed-were provided for comfortable living in different seasons and at different times of the day. The streets were narrow and shaded by overhangs, balconies and the building opposite.
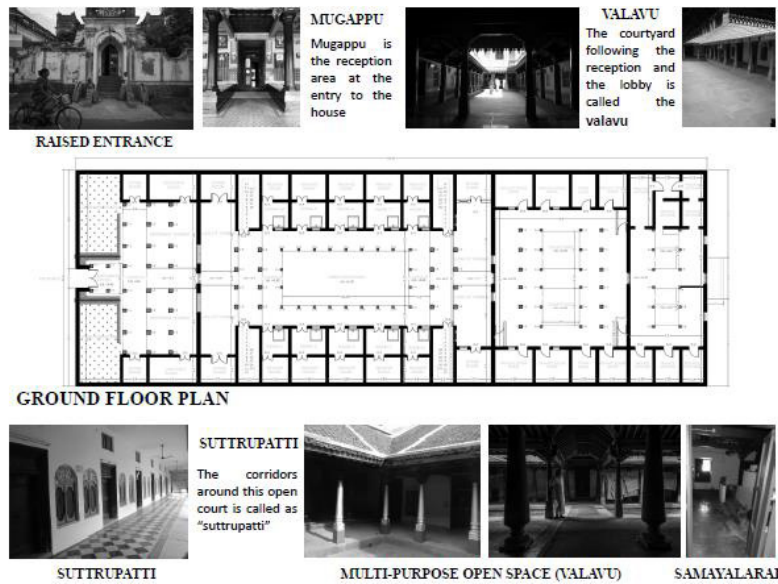

Figure 4. Spatial Planning in the Palatial Mansion of Chettinadu (Source: Author)

\subsection{Types of buildings and styles of architecture}

The Chettiars of the Chettinadu were a people originally from the village of Poombukar near the coastal area of Tanjore. They settled the area in the middle of the 19th century and their invaluable inscriptions depict how they built temples and spread Hinduism. The built heritage of Chettinadu includes the monuments, artifacts, structures, and temple precincts possessing historic, aesthetic or architectural significance located in areas with scenic natural geography. 
The southern India region of Chettinadu in Tamil Nadu has a strong cultural identity epitomized by its palatial mansions (Figure 5) and is one of the few remaining sites in the state where visitors can see the distinctive Tamil architecture. Here the palaces of the rajas have been converted to heritage hotels and resorts but due to negligence, they have started to decay or have even been systematically dismantled to reuse the construction materials (Arche-S., 2007).

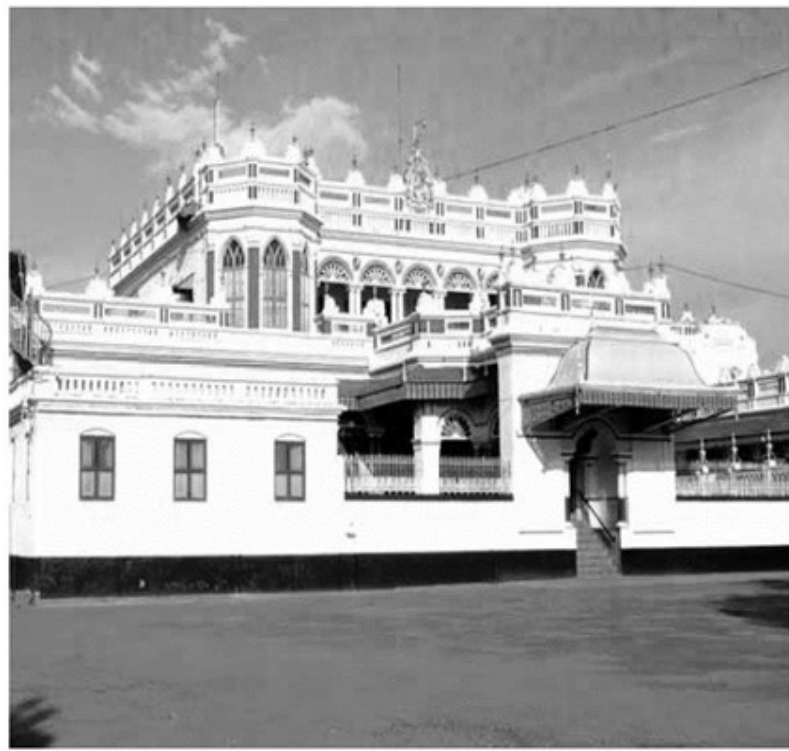

Figure 5. The Chettinadu Palace, Kanadukathan (Source: Concept paper, UNESCO, New Delhi)

The settlement of Chettinadu followed a grid pattern manifesting the cultural components of the clan, caste, kinship, and joint family in the spatial arrangement of the houses. The palatial homes, Erys, Ooranis, and Clan temples (Figure 6) are unique town planning features, the palatial mansions were designed to be identical but varied in size, details and embellishment (Meenakshi et al., 2010). The village water supply depended on rain water harvesting and the varied designs of the mansions and settlement patterns were modified to accomplish this. The houses in this region were built so as to lie along an east-west axis, which invites shadows, breezes and coolness inside them. The walls of these mansions were made of baked brick and Chettinadu lime plaster with terracotta tiles used for roofing that creates a cool living space. The floors consist of local Athangudi tiles particular to the region. The doorways of the mansions have exquisite wooden work with lintel panels above the main entrances depicting illustrations from Hindu mythology. The courtyards are bracketed with Burma teak wood, rosewood and satin wood. Initially, columnar and tabulated patterns were used for construction, but later on due to the influence of the colonial powers the Chettiars began to include arches on the facades of mansions (Figure 7). These facades were further embellished with geometric patterns, sculptures of Hindu gods and goddesses, British benefactors, flora, and mythical creations with multiple color schemes, which developed into the unique architectural character known as the Chettinadu style (Vasulingam, V., \& Vedamuthu, R., 2014).

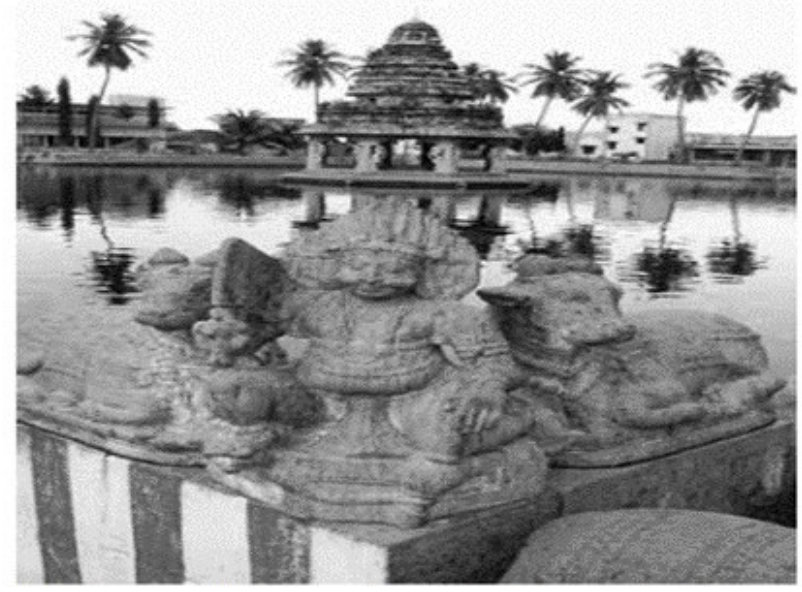

Figure 6. Oorani in Koviloor (Source: Concept paper, UNESCO, New Delhi)

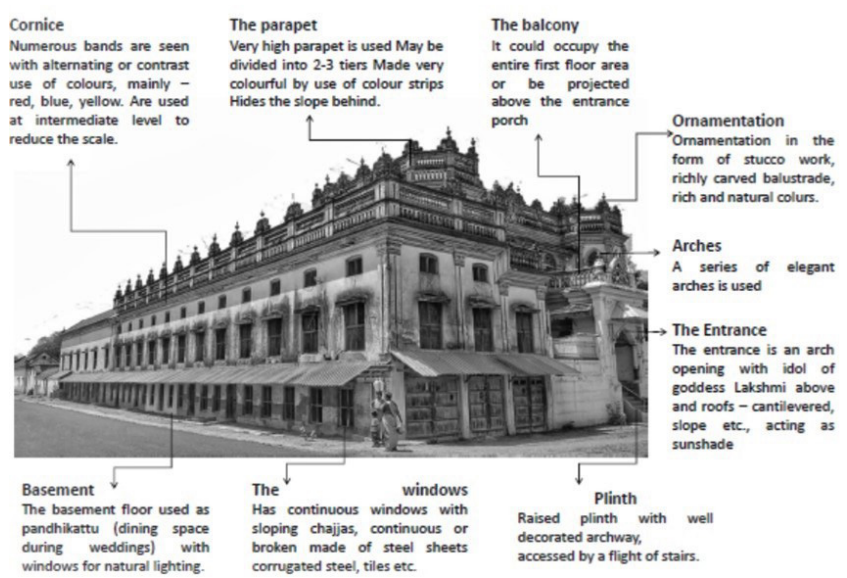

Figure 7. Exterior Building Elements in the Palatial Mansion of Chettinadu (Source: Author)

\section{Methodology}

Our methodology aims to develop an objective framework for protecting and enhancing the heritage values of Chettinadu, its setting, built heritage and people, which have significant historical, religious, and environmental importance and architectural distinction. To achieve this, an analysis of the values in the built heritage of Chettinadu is done. Extensive experience confirms that assessing the value of the built heritage is an essential first step in the process of conservation. (Avrami, 
E., 2000). It is necessary for several reasons to state clearly all the values of a given place (Fielden, 2003). Values give meaning to some things over others and thus turn some items and locations into "heritage." Values are the construction characteristics most identified by modern individuals, the comparative value of values is empirically determined by the decisions taken by those to whom the structures are essential. Conservation must maintain and, if possible, improve the intrinsic flavour and meaning of cultural property for individuals to be truly useful. A specified set of values will assist to methodically determine overall requirements for town planners in selecting suggested procedures as well as in determining the magnitude and nature of individual procedures.

\subsection{Values in the built heritage}

Our strategy for examining the built heritage of Chettinadu involved collecting samples from each cluster and analyzing them based on defined values associated with the buildings. Several parameters were used in the selection of the villages for in-depth analysis. They are categorized as historical interest, architectural merits, group values, social values and local interest, rarity, aesthetical and symbolic values. Figure 8 shows the four major categories of values and their sub-categories that we use in this study. The values were identified from a similar literature review and scaled to fit our study area, Table 2 contains a description about each sub-category.

Table 2. List and description of Values studied in the built-heritage of Chettinadu

\begin{tabular}{|c|c|c|}
\hline Indicators & Variables & Description \\
\hline \multirow{4}{*}{ 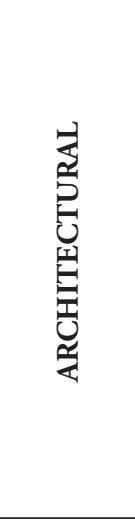 } & $\begin{array}{l}\text { Construction } \\
\text { techniques }\end{array}$ & The unique construction techniques of Chettinadu are a key component in setting the architectural value \\
\hline & Materials & $\begin{array}{l}\text { Building the Chettinadu mansions involved importing supplies from many places at great expense and } \\
\text { difficulty. }\end{array}$ \\
\hline & Aesthetic & $\begin{array}{l}\text { Aesthetic values arising from differences in culture, are defined by art historians, but public acceptance of } \\
\text { change is slow. }\end{array}$ \\
\hline & Styles & $\begin{array}{l}\text { The determining factors for architectural integrity are the characteristics of style, special architectural } \\
\text { features, materials and neighbourhood of the building. The buildings, which are historically important for } \\
\text { their architectural design or significant style, decoration and artistry, composition or particular building } \\
\text { types, possess architectural value. }\end{array}$ \\
\hline \multirow{5}{*}{ 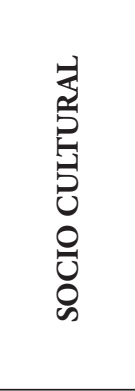 } & Age & The buildings ' age plays a significant role in evaluating the value of the built heritage. \\
\hline & $\begin{array}{l}\text { Historical } \\
\text { Significance }\end{array}$ & $\begin{array}{l}\text { Chettinad is the Nattukottai Chettiars ' homeland, also known as the Nagarathars. It's a successful } \\
\text { community of banking who has a remarkable history. }\end{array}$ \\
\hline & Cultural & The life style and rituals of the Chettiar community add important cultural value to the built heritage. \\
\hline & Symbolic & $\begin{array}{l}\text { Symbolic values represent how individuals derive sensory and intellectual stimulation from a particular } \\
\text { location. }\end{array}$ \\
\hline & Social & $\begin{array}{l}\text { Social values are largely affeced by emotional values, but also by the sense that they are part of a place and } \\
\text { a group }\end{array}$ \\
\hline \multirow{3}{*}{ 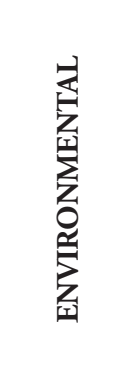 } & $\begin{array}{l}\text { Landscape } \\
\text { setting }\end{array}$ & Chettinadu's characteristic landscaping forms create a unique architectural ensemble. \\
\hline & $\begin{array}{l}\text { Waterbodies } \\
\text { - Erys \& } \\
\text { Ooranis }\end{array}$ & A planned water management system is a unique feature of the Chettinadu towns. \\
\hline & $\begin{array}{l}\text { Ecological } \\
\text { profile }\end{array}$ & The sacred groves in the region are an environmental asset with an important cultural landscape value. \\
\hline
\end{tabular}




\begin{tabular}{|l|l|l|}
\hline \multirow{2}{*}{} & Use Value & $\begin{array}{l}\text { The context of a use value derives from its utilitarian service to culture. Usevalue appears to be much } \\
\text { nearer to the requirements of a 'reflective society ' and cultural heritage social access. }\end{array}$ \\
\cline { 2 - 3 } & $\begin{array}{l}\text { Non-use } \\
\text { Value }\end{array}$ & $\begin{array}{l}\text { Nonuse values are the satisfaction obtained from "cultural heritage characteristics which can be classified as } \\
\text { non-rival and non-exclusive." }\end{array}$ \\
\cline { 2 - 3 } & $\begin{array}{l}\text { The heritage option value refers to the wish of an individual to preserve the option to use the services in } \\
\text { the future. }\end{array}$ \\
\cline { 2 - 3 } & Option & The bequest value represents the value for future generation attached to the built heritage. \\
\hline
\end{tabular}

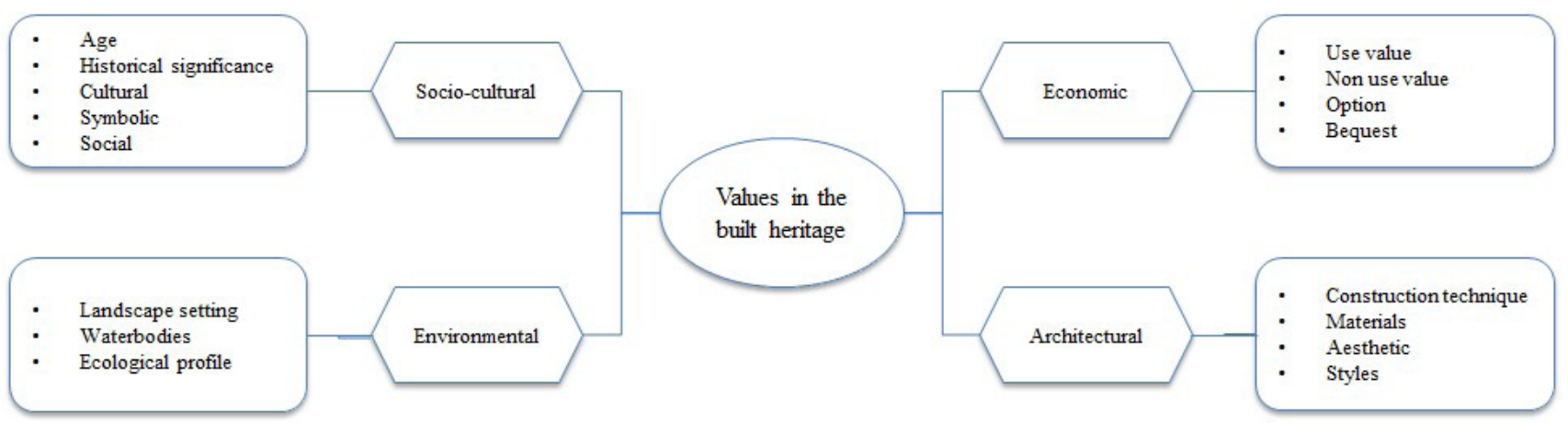

Figure 8. Classification of Values in the built heritage (Source: Author)

\subsubsection{Architectural value}

Focused mainly on aspects related to construction techniques, materials used, styles and aesthetics, this value is evaluated in our search via a set of absolute standards. The buildings of the Chettinadu region are therefore confronted with these standards to judge their special significance. This method joins Kalman's method of evaluating historic buildings in Canada (Kalman, H., 1980).

\subsubsection{Social cultural value}

Social cultural value underlines the connection between the importance for modern societies of the historic setting. Indeed, it includes belonging to places, sense of identity and spiritual association (Jones, S., 2017). In our study, we consider several sub social values, which are age, historical significance, and cultural, symbolic and social values.

\subsubsection{Environmental value}

Through this value, we assess the contribution of the historical building of Chettinadu in the general ecosystem of the region and its landscape. Indeed, this value highlights how Chettinadu's characteristic landscaping forms create a unique architectural ensemble. Otherwise, Intrusive new construction may affect negatively this coherence (Kalman, H., 1980).

\subsubsection{Economic value}

A survey on the economic potential of the region in terms of the wood in the houses could be highlighted. In fact, the palatial mansions in the Chettinadu region is an embellishment of a rich architectural heritage with teak carved doors, pillars and rafters used in the building. The dismantling and sale of the timber in the houses earn a lot of revenue, but the intention behind this conservation program is to stop this antique sale and conserve the houses intact. The economic value of the region is focused from a different perspective of analysing the cultural benefits, bequest value and the tourism. The region has a living cultural heritage which itself is attracting a major visitors, by improving the awareness of the region. Many other activities profit from the revenue distributed to cultural employees, which is the basis of a multiplier method of expenses.

Tourists will spend their own funds not only on immediate cultural consumption, but on accommodation, food, other recreational activities, souvenirs, etc., which will induce another multiplier method of spending. This introduction must be prudent as we will attempt to show later, but it must be implemented if we really want to see a new lever for economic and social development in heritage.

\subsection{Survey methodology}

A statistically relevant survey about the values of historic buildings was conducted to acquire specific data on the peoples' attitudes towards the built heritage. Our analysis utilized a mixed-methods approach, the most suitable for data collection, consisting of face-to-face interviews along with semi-structured questionnaires to generate qualitative and quantitative data. Information was collected from a randomly chosen group of inhabitants of the heritage 
buildings, residing in the Kadiapatti, Kanadukathan, Chocklingam Pudur villages of the Chettinadu region. Heritage buildings includes temples, heritage hotels, public markets, palaces and clan temple gatherings. This method was preferable as it allowed us to obtain varied opinions and responses from the people who actually lived in the historic buildings and in some cases were even taking care of them.

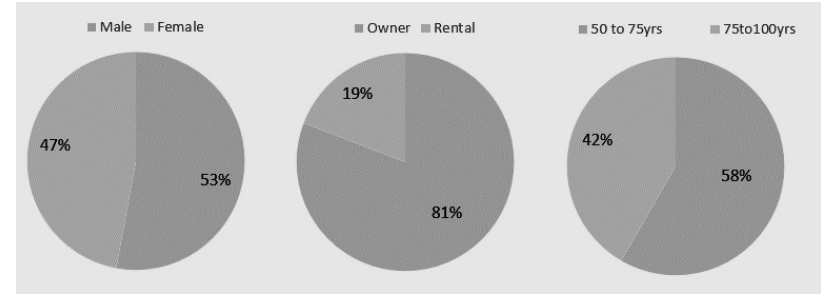

Figure 9. Respondents' gender, buildings' occupancy and buildings' age distributions (Source: Author)

Interviews were conducted and questionnaires were distributed randomly. Because of constraints in time, manpower and finances, the number of subjects included in the study was limited to only 240 although this number was deemed statistically relevant. Figure 9 gives more details about the respondents' gender, building's occupancy and building's age. The survey's questionnaire was comprised of three sections with both open and close-ended questions designed to meet our objectives. The first section consisted of a response sheet to evaluate the importance and potential of the built heritage. The respondents rated the level of importance of the values on a numerical scale from 1-5 based on a 5-point Likert Scale. The second section asked respondents to give their opinions on the current state of conservation of the built heritage. The answers presented ranged from 'Very Bad' to 'Excellent', 'Not Interested' to 'Very Interested' and 'Not Important' to 'Very Important' based on the level of awareness on preservation of heritage buildings and monuments visited by the respondents. The third section attempts to measure the respondent's perceptions and attitudes towards the conservation of specific values. It also indicates the interval of visits made by the people to heritage buildings. The interest in joining conservation efforts is ascertained as well. In the fourth section, the respondents were asked to scale the values in the built heritage of Chettinadu and their preferences towards each value.

\subsection{Survey results}

The first result of the survey concerns the respondents' interest on the conservation of the built heritage of the region. Figure 10 highlights the distribution of different answers. It shows that $79 \%$ of respondents believe that the conservation of the built heritage of the region is important.

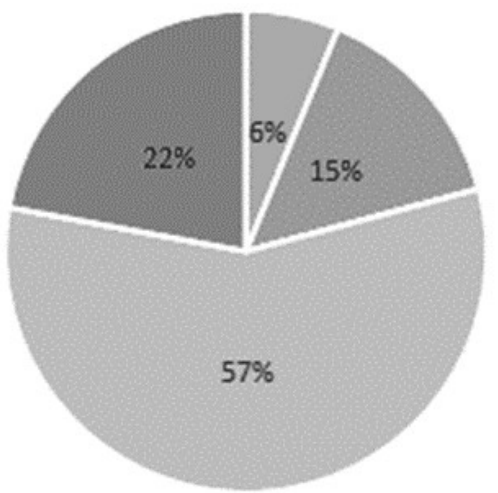

" Not Important " Neutral = Important = Very Important

Figure 10. Interest in Conservation of the built heritage (Source: Author).

The second result highlights the importance of the built heritage as living evidence for future generations. Figure 11 shows that $71 \%$ of respondents confirm the importance of the built heritage. Only $6 \%$ of respondents believe the opposite.

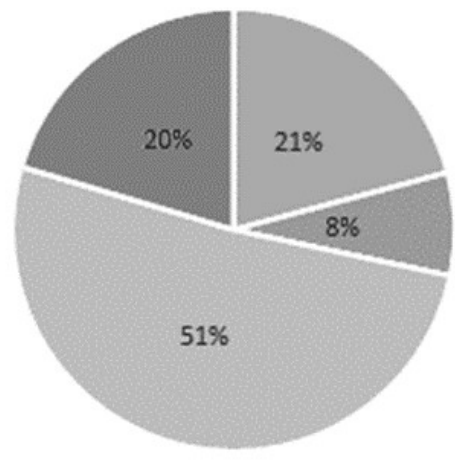

"Sightly Important " Neutral " Important " Very Important

Figure 11. Heritage importance in the built heritage (Source: Author).

Concerning unique features, respondents show an interest to the architectural uniqueness of the region, the cultural aspects and the landscape settings. Figure 12 shows the distribution among respondents of these aspects.

Concerning the reconstruction of the buildings, $85.4 \%$ of the respondents felt that the buildings must be considered for reconstruction while $14.6 \%$ of respondents disagreed. In terms of specific construction needs, 115 (47.5\%) respondents said that walls needed repair, while $9.2 \%$ voted for the roof to be fixed. Interestingly, it was found that buildings 50 to 75 years old needed more work than the older ones. Structural failure was given as the major reason for reconstruction by 106 (44.2\%) of the participants. Only 
$5.4 \%$ said that lack of awareness of the higher value of the heritage buildings was a reason for reconstruction. Many respondents indicated a desire for new services and amenities to be a part of the renovation with $171(71.3 \%)$ asking for car or two-wheeler parking and $7.1 \%$ of the participants pleading for air conditioning.

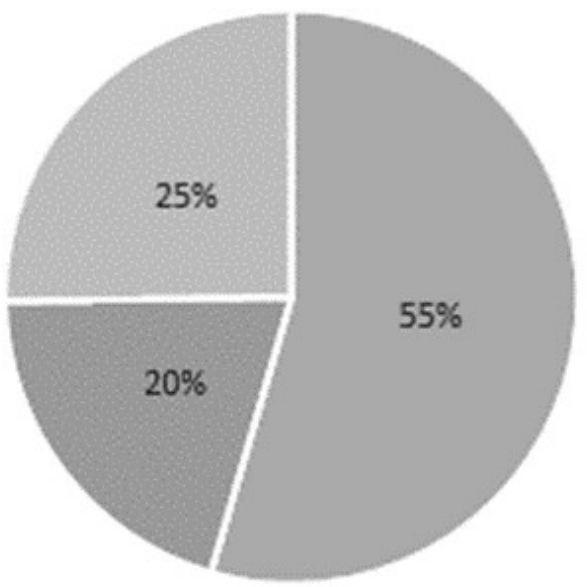

\section{" Architectural | Cutural " Landscape Setting}

Figure 12. Unique Features in the built heritage of Chettinadu Region (Source: Author).

Finally yet importantly, we computed a total score to determine the respondents' perceptions of the environmental, economic, cultural and architectural values. We analyzed data using frequencies, score for each category. Consequently, we computed a final score as highlighted in table 4.

\section{Results and Discussions}

The findings of the research show that while four variables factors (Architectural, Socio- Cultural, Environmental and
Economic Factors) have substantial relations with the general variables, architectural and socio-cultural factors seem to be more crucial that impact the built heritage as a whole. This finding can be useful to cultural / heritage preservation planners and marketers in formulating policies to preserve or improve their competitiveness. In other words, destination promoters would be able to understand which target attribute to allocate the funds to them. The research thus helps to understand the significance of cultural \& heritage values that Chettinadu individuals perceive. Conservation has come to be seen as "a complex and continual process that involves determinations about what constitutes heritage, how it is used, cared for, interpreted, and so on, by whom and for whom" (De la Torre, M., 2013). Decisions about conserving and preserving are also obviously described, to a large extent, by cultural environments, social trends, political and economic powers which continue to modify themselves (Avrami, E., 2000). The first step towards conservation of the built heritage is to acknowledge the values and their significance. This research tried to identify the values associated with the built heritage of Chettinadu in which assessment of the values demonstrated the importance of each component in the built heritage. The survey of values in the form of charts and tables provides a framework for generating viable conservation plans and implementing sustainable conservation policies. We recommend that local self-governing bodies provide a medium for effective discussion at the community level about the importance of architectural values (Kesavapany, K., \& Latif, A., 2016). A well-planned and futuristic vision for integration of heritage buildings should be intensified within the planning agencies and the local stakeholders (Chari, K., 2015).

The complex situation with respect to conservation has emphasized the importance of addressing values as unifying elements in the search for a viable approach. We do the best we can within our cultural context and it will be up to future generations to find their own ways to create a sustainable heritage environment. We must accept that those who come

Table 3. Types of Values and its Average Index

\begin{tabular}{lllllll}
\hline Types of Values & Frequency & & & & \\
& $\begin{array}{l}\text { Strongly Agree } \\
(\mathbf{5})\end{array}$ & $\begin{array}{l}\text { Agree } \\
\mathbf{( 4 )}\end{array}$ & $\begin{array}{l}\text { Neutral } \\
\mathbf{( 3 )}\end{array}$ & $\begin{array}{l}\text { Disagree } \\
\mathbf{( 2 )}\end{array}$ & $\begin{array}{l}\text { Strongly } \\
\text { Disagree } \\
(\mathbf{1})\end{array}$ & Average Index \\
\hline Economical & 25 & 95 & 90 & 35 & 5 & 3.4 \\
Cultural & 55 & 150 & 35 & 5 & 5 & 3.98 \\
Environmental & 40 & 85 & 60 & 50 & 15 & 3.34 \\
Architectural & 45 & 150 & 45 & 10 & 0 & 3.92 \\
\hline
\end{tabular}


after us will have different values and may disregard those things that were important to us.

Value is a mental and conceptual thing, but once the idea is formed it has a direct link with the identity and culture of a society. Key parts of the constructed heritage need to be understood. Therefore, we also recommend:

- Creating awareness about the uniqueness and potential of the built heritage of Chettinadu through camps and media.

- Promoting heritage tourism by focusing on both tangible and intangible values.

- Interventions in the historic fabric should give due respect to defined heritage values.

- A sustainable conservation strategy needs to incorporate socio-cultural, architectural and environmental values.

- Public participation should be encouraged to get better results in the conservation plan.

\section{Conclusion}

Through this study, we studied the historical background of heritage areas and buildings in the Chettinadu region. Indeed, using a scoring system to assess different heritage built values, we attempt to highlight the significance of this region for humanity in general and Indian people in particular. The scoring system was developed using a set of variables from the literature, which are architectural, socio-cultural, environmental and economical values. We decomposed our survey to several sections to assess each value by interviewing 240 subjects related somehow to the studied region. Different results was then highlighted in the paper especially the interest of respondents in the conservation of the built heritage and its importance for this region. Architectural value is in the top of the values judged as one of the unique features in the built heritage of Chettinadu. We believe that the findings of this research have several implications on government policies, conservation priorities and of course the public community that should be aware of different risks affecting this region. Furthermore, we have taken into consideration the limitations of our findings, especially the correlation between the different values with the respondents' social and economic situation. Consequently, a natural perspective of research may be a deep dive analysis into this correlation.

\section{References}

Australia ICOMOS (1979) "The Australia ICOMOS Guidelines for the Conservation of Places of Cultural Significance ('Burra Charter')." Accessed March 17, 2016. http://australia.icomos.org/wp-content/ uploads/Burra-Charter_1979.pdf
Australia ICOMOS (1988)Guidelines to the Burra Charter: procedures for undertaking studies and reports. Electronic document, http://www.marquiskyle.com. au/bcstudies.htm, accessed September 27, 2012.

Australia ICOMOS (1999). "The Burra Charter" Electronic document, Retrieved from http://australia.icomos. org/publications/charters.

Avrami, E. (2000). Values and heritage conservation. Conservation: The Getty Conservation Institute Newsletter, 15(2), 18-21.

AZMI, Nur Farhana; AHMAD, Faizah; ALI, Azlan Shah (2015) Heritage place inventory: A tool for establishing the significance of places. Journal of Design and Built Environment, 15, n. 1, ISSN 2232-1500. doi: https:// doi.org/10.22452/jdbe.vol15no1.3. 15-23.

Cathy. L. Costin, (1993). Legal and Policy Issues in the Protection of Cultural Heritage in South Asia and the Pacific. In Margaret G. H. Mac Lean (Editor), Cultural Heritage in Asia and the Pacific: Conservation and Policy. Proceedings of a symposium held in Honolulu, Hawaii, USA, 8-13.

Chari, K. (2015). In search of roots: the start of a journey to uncover the ancient Hindu concept of' Art as Experience in India, today. An exploration of Indian metaphysics as the foundation of this concept (Doctoral dissertation).

Choay, F. and O Connell, L. M. (2001). The invention of the historic monument.

De la Torre, M. (2013). Values and héritage conservation. Heritage \& Society, 6(2), 155-166.

Feilden, B. M., and Jokilehto, J. (1998). Management guidelines for world cultural heritage sites.

Feilden, B. (2003) . Conservation of Historic Buildings. Oxford: Elsevier.

Ferdous Farhana Huq, Rabeya Akter, Roxana Hafiz, Abdullah Al Mamun, Mashrekur Rahman.(2014) "Conservation planning of built heritages of Old Dhaka, Bangladesh", Journal of Cultural Heritage Management and Sustainable Development, 244-271

Frey Bruno. (1997). "The Evaluation of Cultural Heritage: Some Critical Issues." In Economic Perspectives on Cultural Heritage, edited by M. Hutter and I. Rizzo, 31-49. Basingstoke: Palgrave MacMillan. 10.1007/978-1-349-25824-6_3.

Goussous, J. S. and Al-Hammadi, N. A. (2018). Place attachment assessment of a heritage place: A case study of the Roman amphitheater in downtown Amman, Jordan. Frontiers of Architectural Research.

Hearn, M. F. (1990). The Architectural Theory of Violletle-Duc Readings and Commentaries. Massachusetts Institute of Technology, Cambridge, Massachusetts. 
ICOMOS Australia (1999). The Australian ICOMOS Charter for Places of Cultural Significance, Australia.

ICOMOS New Zealand (2010) "ICOMOS New Zealand Charter for the Conservation of Places of Cultural Heritage Value." Auckland: ICOMOS New Zealand. Accessed 17 March 2016.Retrieved fromhttp://www. icomos.org.nz/docs/NZ_Charter.pdf.

Indian Heritage Passport Programme: on the Chettinad trail in Tamil Nadu; a concept paper, Retrieved from https:// unesdoc.unesco.org/ark:/48223/pf0000188788

Johnston, Chris (1992). What is Social Value? A Discussion Paper. Technical Publications Series No. 3. Australian Government Publishing Services, Canberra.

Jokilehto, J. (2002). A History of Architectural Conservation, Oxford: Butterworth - Heinemann.

Jones, S. (2017). Wrestling with the social value of Heritage: problems, dilemmas and opportunities. Journal of Community Archaeology \& Heritage, 4(1), 21-37.

Kalman, H. (1980). The evaluation of historic buildings. Environment Canada, Parks Service.

Kesavapany, K. and Latif, A. (2016). The Singapore Indian Community towards SG100. In 50 Years of Indian Community in Singapore (pp. 131-135).

Kiruthiga, K. and Thirumaran, K. (2017). Visual perception on the architectural elements of the built heritage of a historic temple town: a case study of Kumbakonam, India. Frontiers of Architectural Research, 6(1), 96-107.

Lafrenz Samuels, Kathryn (2008). "Value and Significance in Archaeology." Archaeological Dialogues 15, 71-97.

Lipe, W. D. (1984). Value and meaning in cultural resources. Approaches to the archaeological heritage, 1-11.

Mason, R. (2002). Assessing values in conservation planning: methodological issues and choices. Assessing the values of cultural heritage, 5-30.

MacFarquhar, Neil (2011). Mali City Rankled by Rules for Life in Spotlight. The New York Times January 8: A4.New York.

Meenakshi, M., Visalakshi, R. and Muthaiya, S. (2010). The Chettiar Heritage. The Chettiar Heritage Press.
Margarita Díaz-Andreu (2017). Heritage Values and the Public, Journal ofCommunity Archaeology \& Heritage, 4:1, 2-6, DOI: 10.1080/20518196.2016.1228213

Orbaşlı, A. (2008). Architectural Conservation: Principles and Practice. Oxford: Blackwell Science.

Pereira Roders, A. (2007). "Re-architecture: lifespan rehabilitation of built heritage", $\mathrm{PhD}$ thesis, Technische Universiteit Eindhoven, Eindhoven.

Riegel, A. (1996). The modern cult of monuments: its essence and its development. Historical and Philosophical Issues in the Conservation of Cultural Heritage (Los Angeles: Getty Conservation Institute,), 69-83.

Ruskin, J. (1885). The seven lamps of architecture 521, John B. Alden.

Ruskin, J. (2013). The Lamp of Memory (1849). Historical Perspectives on Preventive Conservation, 6, 2.

Seetha Rajivkumar and Thirumaran Kesavaperumal (2018). Investigating the residents' attitude towards the preservation of palatial houses built heritage in Chettinad region, Tamil Nadu, Journal of Community Archaeology \& Heritage, DOI: 10.1080/20518196.2018.1529549 .

Soheir M. Hegazy (2015). Conservation of historical buildings - The Omani-French museum as a case study,HBRC Journal, 11:2, 264-274, DOI: 10.1016/j. hbrcj.2014.03.010.

UNESCO (2014). Chettinad, Village Clusters of the Tamil Merchants.. http://whc.unesco.org/en/ tentativelists/5920/

Vasulingam, V. and Vedamuthu, R. (2014). Structural strategy and construction system in the case of traditional beri-chettiar dwellings in Chennai (18501950). SAHC2014 - 9th International Conference on Structural Analysis of Historical Constructions F. Peña \& M. Chávez (eds.) Mexico City, Mexico, 14-17 October 2014

Walker, Meredith (1998). Protecting the Social Value of Public Places: An Illustrated Guide. Australian Council of National Trusts, Canberra. 
"Film offers students an opportunity to connect the theoretical discourses we engage in classes to a range of social issues represented through the lens of Hollywood movies" 